\title{
Research \\ Continuity and Change in Social-ecological Systems: the Role of Institutional Resilience
}

\author{
$\underline{\text { Elke Herrfahrdt-Pähle }}^{1}$ and Claudia Pahl-Wostl ${ }^{2}$
}

\begin{abstract}
In recent years recurring political, economic, and environmental crises require questioning and re-evaluating dominant pathways of human development. However, political and economic frameworks seem to encompass deeply rooted resistance to fundamental changes (e.g., global financial crisis, climate change negotiations). In an effort to repair the system as fast as possible, those paradigms, mechanisms, and structures that led into the crisis are perpetuated. Instead of preserving conventional patterns and focusing on continuity, crises could be used as an opportunity for learning, adapting, and entering onto more sustainable pathways. However, there are different ways not only of arguing for sustainable pathways of development but also of conceptualizing continuity and change. By focusing on institutions, we illustrate the tension between the concepts of continuity and change, how they interact, and how they build or degrade institutional resilience. The analysis draws on empirical research in South Africa and Uzbekistan, which were locked in persistent regimes over decades. Faced with the challenge to transform, Uzbekistan chose a pathway of institutional continuity, while South Africa opted for comprehensive reforms and a high level of change. Based on these case studies, we illustrate the advantages and disadvantages of institutional continuity and change. Elements of institutional continuity during times of transformation include preserving key institutions, which define how the rules are made; maintaining social memory; providing transparency of reform processes and allowing them time to take effect. Elements of institutional change required during phases of consolidation include flexible legislation; regular reviews; and adaptation of legislation during and after implementation.
\end{abstract}

Key Words: adaptation; institutions; persistence; resilience; transformation; water governance

\section{INTRODUCTION}

Current political and economic systems seem to encompass deeply rooted resistance to questioning and re-evaluating dominant pathways of development when faced with sudden surprising change (Handmer and Dovers 2009). Recent examples are climate change negotiations or the global financial crisis, which exhibit the reluctance of decisionmakers to redirect paradigms, mechanisms, and structures that led to a problem or crisis. The goal often becomes one of repairing the system as fast as possible to where it was before the crisis, such as through economic stimulus packages and financial market reforms in case of the financial crisis (Palley 2009).

Climate change will impact many spheres of human life, such as by impacting the water cycle. Changed precipitation patterns and extreme events, in particular, droughts and floods, are likely to occur, but they are hard to predict. Given the increase in both uncertainty and surprise in relation to climate change, the resistance to change in social systems might turn out to be a major drawback, increasing vulnerability (Handmer and Dovers 2009). Repairing the system to what it was before, without learning and adapting to change, is seldom a sustainable strategy (Holling and Meffe 1996), and certainly not if the mindset behind the repairs does not see the fundamental dependence of economic progress on the ecological life-support capacity of the Earth system (Rockström et al. 2009). A major challenge consists of having the capacity to make use of abrupt, often surprising change, often perceived as crisis, as opportunity for shifting towards sustainability pathways. Social-ecological resilience, i.e., the capacity of a system to absorb disturbance and at the same time learn from disturbances and reorganize (Folke 2006), will be required to allow for transformation at other levels, create a fundamentally new system, and enter a new pathway for development (Walker et al. 2004, Folke et al. 2010). Adaptation, i.e., the capacity to deal with disturbances through learning and adjusting, will be required to persist on the new development path (Folke 2006).

There are different ways of arguing for favorable pathways of development and thus of conceptualizing continuity and change. Ecology stresses evolutionary principles and the role of change and disturbance for long-term system functioning and resilience (Gunderson and Holling 2002). By contrast, economics and political science emphasize path dependence, inertia, and robustness (North 1993, Pierson 2000, David 2002). They underscore the importance of stable social systems (such as stable economic and social institutions) as a basis for innovation and (economic) development. Ecology as well as economics and political science argue in favor of novelty and innovation as building blocks of development but assume that innovations develop from different sources.

We attempt to shed light on the tension between the concepts of stability and continuity, on the one hand, and change and disturbance, on the other. We focus on institutions as links 
between social and ecological systems (Folke et al. 1998), and on the question of how institutional change and institutional continuity interact and build or degrade institutional resilience. The aim is to explore the tension between continuity and change in light of resilience theory and institutional resilience in two case studies: South Africa and Uzbekistan.

The remainder of our discussion is structured as follows. First, serving as the conceptual background, the concepts of institutional resilience as well as continuity and change in social-ecological systems are elaborated. After some remarks on methodology, the South African and Uzbek water sectors are examined regarding institutional continuity and change, and in particular, their contribution to increasing or decreasing the institutional resilience. Based on the case studies, we propose drivers and possible elements of (institutional) continuity during times of transformation, as well as elements of (institutional) change during phases of consolidation.

\section{INSTITUTIONAL RESILIENCE}

Institutions, i.e., the rules and norms that govern human interaction, are inherently conservative (Gupta et al. 2010). They reduce uncertainty by helping individuals base expectations on the actions of others (North 1990). The institutional (sub-)system thus guides the operations of all human beings within a social-ecological system (SES) (Holl 2002). Institutions provide the basis for the use of natural resources and thus link social to ecological systems (Folke et al. 1998). It has proven helpful to distinguish between formal and informal institutions (Williamson 2000). Formal institutions are all kinds of legally binding norms, such as constitutions, laws, and policies in the political system (e.g., the governance structure), the economic system (e.g., property rights), and the enforcement system (e.g., the judiciary; Pejovich 1999). Formal institutions can be divided into three categories resembling different degrees of continuity and change: constitutional rules (defining the authority of collective actors; developing within several decades), collective choice rules (enabling collective choices about resource use by authorized actors; changing within several years or decades), and operational rules (defining the choice sets of individuals; cycling or moving within several months or years) (Holling et al. 2002, Ostrom 1990, 2005, Paavola 2007). In contrast, informal institutions include cultural norms, such as customs, traditions, and moral values-the socially shared rules that exist and are enforced outside of the formal governance structures (Helmke and Levitsky 2004). Formal and informal institutions can increase or decrease the resilience of an SES (Gunderson et al. 1997, Adger 2003, Berkes et al. 2003). An institutional system (as a subsystem of the SES) is resilient if it can

1. withstand disturbances and thus provide stability and reduce uncertainty in the SES (such as by defining water abstraction quotas so that they can be applied in waterscarce years), and
2. change (and thus provide flexibility) in the medium to long term to react to the uncertainties of a changing environment and/or changes in the social system (e.g., adjust water quotas if water availability has dropped over a longer time period due to climate change) (Young 2010).

Institutional resilience increases institutional diversity (Huitema et al. 2009). This diversity includes a set of relatively stable institutions that are not easily changed and which ensure continuity (such as a constitution) and others that are easier to change and thus provide for the flexibility needed to react to external changes (such as water policy, water management rules) (Herrfahrdt-Pähle 2010). Institutional resilience thus is about managing continuity and change in order to adapt an institutional system while not changing it so often that stakeholders lose their trust in the institutional setup (Folke et al. 1998). The appropriate mix of continuity and change varies over time and results in periods of institutional persistence interrupted by periods of abrupt change (Young 2010).

\section{CONTINUITY AND CHANGE IN SOCIAL- ECOLOGICAL SYSTEMS}

One heuristic model for dealing with the resilience of socialecological systems and the varying degrees of continuity and change of a system over time is a set of nested adaptive cycles, i.e., a panarchy (Gunderson and Holling 2002). Applied to institutions, the adaptive cycle suggests that institutions evolve as new institutions are recognized (r-phase), implemented (Kphase), experience crisis ( $\Omega$-phase), and finally compete with other institutions ( $\alpha$-phase) (Janssen 2002). The nested cycles can be understood as the different forms of formal institutions (i.e., constitutional rules, collective choice rules, and operational rules) (Ostrom 1990). Institutional resilience in this notion of the temporal scale is the appropriate mix of changing faster cycles and stable slower ones. The higher levels of the panarchy are usually expected to provide opportunities for memory and learning, while the lower levels innovate and renew (Gunderson and Holling 2002). If, however, the higher levels themselves undergo renewal, this provides room for broader changes across levels (Walker et al. 2006).

\section{Persistence, adaptation, and transformation}

The literature identifies three types of change: persistence, adaptation, and transformation (Folke et al. 2010). Persistence refers to an institutional system that changes only incrementally after a disturbance (Gunderson et al. 2006). Such incremental change can, for example, take place at the level of operational rules (Young 2010). Persistence can thus be associated with single-loop learning, learning processes within the current system, i.e., it takes place within the current framework of norms and values without questioning the underlying assumptions (Pahl-Wostl 2009). Incremental changes in everyday practices that improve system 
Fig. 1. Persistence, adaptation, and transformation are often associated with different levels of continuity and change. The persistence of an institutional arrangement is characterized by a high level of institutional continuity. A setting of adaptation often reveals alternating phases of institutional continuity and change, while in transforming social-ecological systems, institutional arrangements undergo comprehensive change.

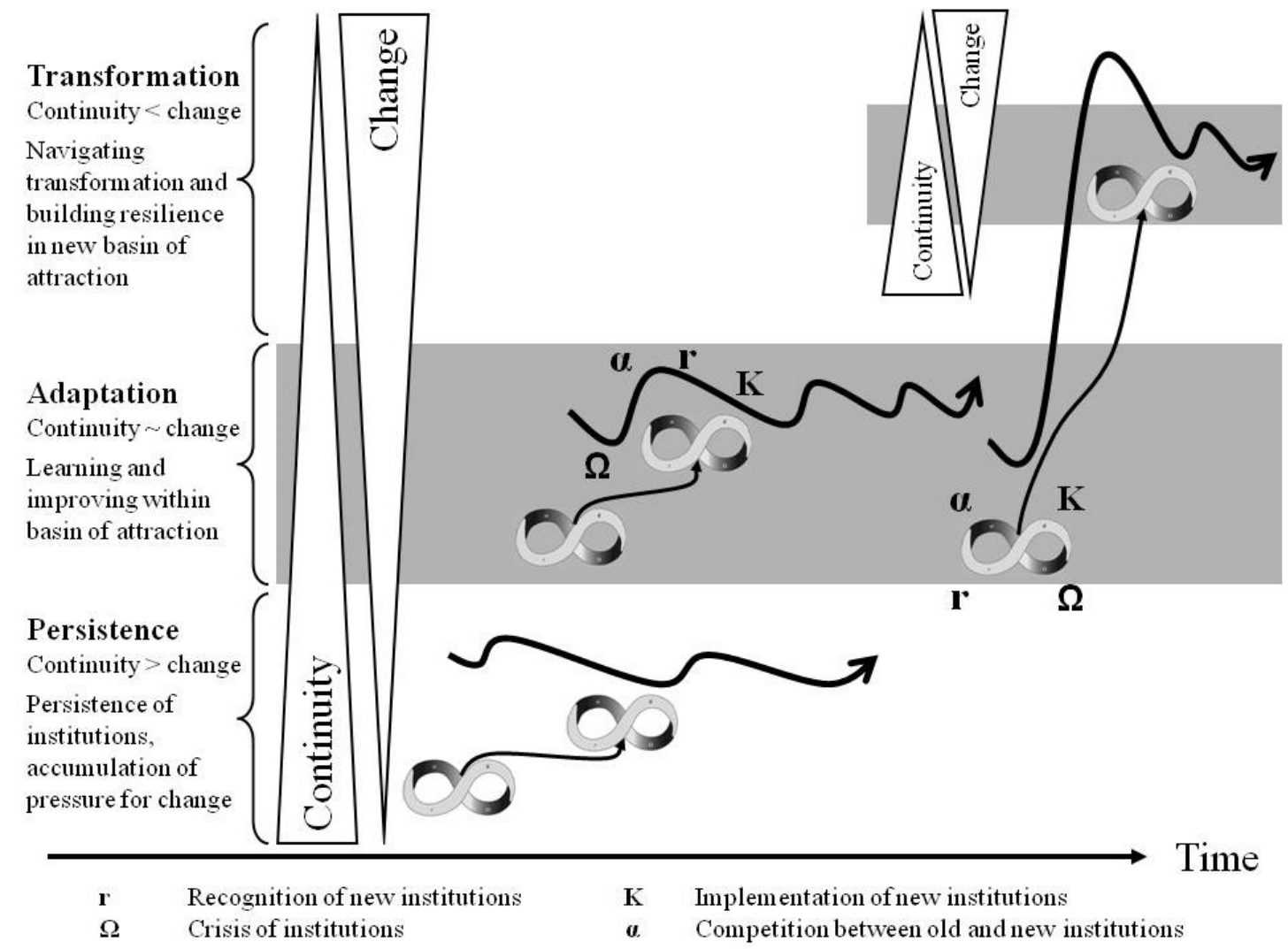

performance, such as adapting the date of crop planting according to changed temperature patterns, can serve as an example. If institutions do not adapt, systems get locked in a command-and-control syndrome that can be highly persistent (Gunderson et al. 1995) (Fig. 1). This state has also been termed pathological state or rigidity trap (Gunderson and Holling 2002, Allison and Hobbs 2004). As a consequence, potential for change accumulates, the system becomes brittle, and small disturbances such as a prolonged drought may cause major inefficiencies or even a breakdown (if, for example, drought relief schemes have not been developed or updated) (Berkes et al. 2003).

With uncertainty and surprise increasing, as can currently be observed through climate change, institutional systems need to become more flexible and adaptive (Handmer and Dovers 2009). Adaptive change refers to the social system's response to shifts in ecological or social systems (Gunderson et al. 2006). Adaptation of the institutional system can be accompanied by double-loop learning, i.e., a learning process that reviews assumptions without questioning the underlying values and norms (Pahl-Wostl 2009). Such a process may, for example, be related to a shift in collective choice rules, such as the competencies of Water User Associations. Adaptive change thus means making appropriate trade-offs between continuity and change, i.e., between stabilizing and destabilizing forces (Holling and Gunderson 2002) (Fig. 1).

An institutional system may, however, also be confronted with a broad mismatch between its functions and its environment, which requires transformation (Folke et al. 2010) (Fig. 1). Transformation relates to the ability of an SES to create a fundamentally new institutional system (Gunderson et al. 2006, Walker et al. 2006, Folke et al. 2010). Such a transformation may, for example, be connected to a change in constitutional rules, such as national water law, if it implies a paradigm shift in water management, e.g., from commandand-control to decentralized, participatory water governance. Transformation can thus be associated with triple-loop learning, implying a learning process that includes the 
questioning and change of prevalent mental models, values, and norms (Pahl-Wostl 2009). The capacity to fundamentally change a system is especially needed when a social-ecological system is trapped in a highly resistant and undesirable regime (Walker et al. 2006).

\section{Different levels of institutional continuity and change in social-ecological systems}

Increasingly uncertain environments force social systems and institutional settings to become more adaptive-more flexible and open to change-in order to be able to admit innovation and adapt to new circumstances (Berkes et al. 2003). However, during transformation, a certain level of continuity and persistence at higher levels is necessary to prevent the institutional system from loss of useful properties (Folke et al. 2010). This continuity can be provided within the institutional system (by durable institutions such as water codes, which enable and sustain an efficient water governance system) or outside the institutional system (such as by the institutional memory of actors) (Young 2010). Systems that allow too much change will encounter loss of memory, while systems characterized by a high degree of continuity will almost certainly experience surprise and generate crisis (Berkes et al. 2003). Even during consolidation and high levels of persistence, institutional systems need to display a certain degree of flexibility and openness to change. Thus, the amounts of continuity and change vary in relation to the phase the system is currently undergoing (Gunderson and Holling 2002 ). During the back loop ( $\Omega$ to $\alpha$-phase) of the adaptive cycle, the amount of change increases, while it decreases during the consolidation phases of the front loop ( $\mathrm{r}$ to K-phase; see bold arrows in Fig. 1). The task is to find the appropriate mix of innovation and conservation, making (institutional) resilience a moving target (Bohensky 2008, Gupta et al. 2010).

\section{METHODS}

Our results are based on both a literature review and field research undertaken as part of the European Union-funded NeWater project (New Approaches to Adaptive Water Management under Uncertainty). During the field research in Uzbekistan (2006 and 2007) and South Africa (2006), empirical data were gathered using semi-structured interviews (34 in South Africa and 54 in Uzbekistan) and three group discussions. The respondents belonged to governmental water management agencies at all levels, ministries related to water issues (agriculture, etc.), farmers' associations, Water User Associations, nongovernmental organizations, international and basin water management organizations, and donor agencies. Ten water users were interviewed, as well as scientists in the fields of water management, governance, and climate change. Reference to these interviews is made with a "P" and the respective interview number.

The cases were chosen due to their similar hydrogeophysical features (especially of the rivers Amu Darya and Orange-
Senqu) and because both countries are undergoing political and economic transformation. Both countries are currently reforming their water governance regimes along the lines of Integrated Water Resource Management (IWRM). These similarities contrast with the countries' different performances in transforming their political and water governance regimes (Table 1). For example, while Uzbekistan ranges low in accountability, government effectiveness, and rule of law, South Africa has been attested average or good performance in these governance indicators (World Bank 2009).

\section{CASE STUDY UZBEKISTAN}

Located in the heart of Central Asia, the Republic of Uzbekistan once belonged to the Soviet Union. The country is characterized by a semi-arid climate, and most of the available water originates in neighboring Kyrgyzstan and Tajikistan. The first impacts of climate change can already be felt in the region: temperatures have been rising faster than the global average and are projected to rise up to $7.5^{\circ} \mathrm{C}$ by the year 2100 (Cruz et al. 2007). Models suggest an overall decrease in annual mean precipitation by $3 \%$ by 2100 (Christensen et al. 2007), which could be accompanied by an increasing frequency of dry spring, summer, and autumn seasons (Cruz et al. 2007).

Since Soviet times, the Uzbek economy has been dominated by large-scale irrigated agriculture (mainly of cotton but recently also wheat) and ranges among the top five producers of cotton worldwide (FAO 2011). Revenues and foreign currency generated through cotton exports sustain large parts of the state budget (Carmel 2005).

Estimates suggest that more than $25 \%$ of the population lives below the poverty line (World Bank 2003). Access to drinking water is relatively high but is deteriorating (WHO 2008). The agricultural sector absorbs $93 \%$ of the amount of available water resources (FAO 2010). The abstraction of large amounts of water from the tributaries to the Aral Sea for irrigated agriculture, inefficient water infrastructure, and ineffective institutions led to the desiccation of the Aral Sea-a major ecological disaster (Herrfahrdt 2004). Particularly during drought years, such as 2000/2001, the water governance system is not able to provide enough irrigation water to all farmers, nor is water distribution equitable (Wegerich 2001).

\section{Institutional continuity and change since independence}

After the breakup of the Soviet Union in 1991, a new constitution was enacted, but it did not lead to major revisions of other laws and regulations. The Act on Water and Water Use (Republic of Uzbekistan 1993) is based on Soviet water law, which entails inefficiencies and overuse (Abdullaev et al. 2007). The Act is outdated and no longer addresses the changed realities of water availability and agricultural production. Water management is strictly centralized, irrigation water remains free of charge (despite a negligible 
Table 1. Basic features of the case studies.

\begin{tabular}{|c|c|c|}
\hline & South Africa & Uzbekistan \\
\hline \multicolumn{3}{|l|}{ Hydrogeophysical features } \\
\hline Climate & Arid/semi-arid & Arid/semi-arid \\
\hline Possible impact of climate change & Rising temperature & Rising temperature \\
\hline (Christensen et al. 2007, Cruz et al. 2007) & Decreasing precipitation & Decreasing precipitation \\
\hline Hydrogeophysical features of rivers & $\begin{array}{l}\text { Orange-Senqu: water formed in mountains } \\
\text { of neighbouring Lesotho, then flowing } \\
\text { through a semi-arid plain, dominated by } \\
\text { (irrigated) agriculture and large-scale } \\
\text { farming }\end{array}$ & $\begin{array}{l}\text { Amu Darya: water formed on glaciers of } \\
\text { neighbouring Tajikistan and Kyrgyzstan, then } \\
\text { flowing through a semi-arid plain, dominated } \\
\text { by irrigated agriculture and farming }\end{array}$ \\
\hline Actual renewable water resources per capita in 2005 (FAO & $1106 \mathrm{~m}^{3} /$ inhabitant/year & $1904 \mathrm{~m}^{3} /$ inhabitant/year \\
\hline 2010) & $\begin{array}{l}\text { i.e., "water stressed" and close to the limit } \\
\text { of "water scarce" }\left(<1000 \mathrm{~m}^{3}\right)\end{array}$ & $\begin{array}{l}\text { i.e., relatively sufficient (but no environmental } \\
\text { flows) }\end{array}$ \\
\hline \multicolumn{3}{|r|}{ 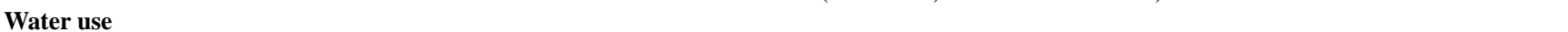 } \\
\hline Total water withdrawal per capita (1998-2002) (FAO 2010) & $279 \mathrm{~m}^{3} /$ inhabitant/year & $2270 \mathrm{~m}^{3} /$ inhabitant/year \\
\hline $\begin{array}{l}\text { Total water withdrawal as a percentage of total renewable } \\
\text { water resources (1998-2002) (FAO 2010) }\end{array}$ & $25 \%$ & $108 \%^{\dagger}$ \\
\hline $\begin{array}{l}\text { Pressure on renewable water resources (values }>25 \% \text { are } \\
\text { considered to be high pressure) (FAO 2010) }\end{array}$ & Moderate & Extremely high \\
\hline $\begin{array}{l}\text { Water withdrawal by agricultural sector (1998-2002) (FAO } \\
\text { 2010) }\end{array}$ & $63 \%$ & $93 \%$ \\
\hline \multicolumn{3}{|l|}{ Transformation and governance indices } \\
\hline Worldwide Governance Indicators: & Average or good & Poor \\
\hline Voice and accountability (percentile rank $0-100)^{\ddagger}$ & 67.8 & 1.9 \\
\hline Political stability (percentile rank 0-100) & 41.6 & 18.2 \\
\hline Government effectiveness (percentile rank 0-100) & 75.4 & 27.0 \\
\hline $\begin{array}{l}\text { Rule of law (percentile rank 0-100) } \\
\text { (World Bank 2009) }\end{array}$ & 56.0 & 10.0 \\
\hline Corruption Perception Index 2009 & $4.7 / 10$ & $1.7 / 10$ \\
\hline (Transparency International 2009) & (rank 55 out of 180$)$ & $($ rank 174 out of 180$)$ \\
\hline Political and economic transformation (status index) & $18 / 125$ & $111 / 125$ \\
\hline Way towards democracy and market economy (management & $10 / 125$ & $117 / 125$ \\
\hline index) (Bertelsmann Foundation 2008) & transformation in progress & transformation blocked \\
\hline
\end{tabular}

$\dagger$ A rate $>100 \%$ is possible since Uzbekistan re-uses part of its agricultural drainage water and because upstream countries eventually do not use the full amount of water allocated to them by international treaties.

$\ddagger$ The percentile rank indicates the rank of a country among all countries in the world ( 0 corresponds to lowest, 100 to highest rank).

water tax), and water resources continue to be state property (Wegerich 2009). This institutional persistence is even more surprising since at the same time the disastrous consequences of the desiccation of the Aral Sea were becoming obvious and drawing worldwide attention (Micklin 1988).

However, the agricultural sector, which is closely linked to the water sector thanks to the great importance of irrigation, underwent several institutional changes. The dismantling of the former state farms and collective farms began shortly after independence. Waves of restructuring and privatization occurred after 1998 (with the new Land Code and several laws on new forms of agricultural production) and 2005 (restructuring of agricultural production units) (Herrfahrdt 2004, Schlüter and Herrfahrdt-Pähle 2011). Nevertheless, the basic structures of the agricultural sector remained unchanged: land still belongs to the state, land ownership is possible only in the form of leasehold (Republic of Uzbekistan 1998), and the Soviet state order system (which secures state control over agricultural production and output) is still in place for the dominant crops (cotton and wheat).

Following these land reforms and the subsequent emergence of thousands of new farm entities, the pressure for a new, local level of water administration, Water User Associations (WUAs), was great. In contrast to previous water management practice, WUAs are supported by donors such as the Asian Development Bank and are aimed at a decentralized and participatory management of water resources by water users (IWMI and SIC-ICWC 2003). However, in 2000 the first pilot WUAs were introduced not by the Ministry of Agriculture and Water Resources but under the personal responsibility of a province governor and through informal connections (Yalcin and Mollinga 2007). Only after these pilot WUAs had 
performed well during the drought years of 2000 and 2001 did the government allow the establishment of WUAs in other provinces (Veldwisch 2008). It must be noted that these WUAs are far from complying with the internationally acknowledged concept of WUAs (especially in terms of participation, independence, decentralization, and adherence to hydrological boundaries), but are instead strongly controlled by the state (Veldwisch 2008).

With the implementation of WUAs, double-loop learning has taken place, but only after significant effort by well-connected people at high levels in the political hierarchy. This change of collective choice rules was, however, not followed by an adaptation of constitutional rules such as the water law to accommodate WUAs. Therefore, WUAs are implemented in an institutionally uncertain environment and, for example, are charged taxes even though they should be non-profit organizations and thus exempt from taxpaying (P 89).

The reforms in the water sector entered the second phase with the Decree on the Main Directions of Agricultural Reform (Republic of Uzbekistan 2003), which stipulates that water management be aligned with hydrological boundaries in order to increase the fit of the social and ecological system (Young 2002, Schlüter and Herrfahrdt-Pähle 2011). Similar to the introduction of WUAs, the implementation of hydrological boundaries was undertaken mainly due to the initiative of a high-ranking senior official within the Ministry (Yalcin and Mollinga 2006). The aim was not so much to make water management more effective but instead to limit the influence of the agricultural sector and local and provincial governors on water distribution by unlinking the boundaries of water management organizations from administrative units (Yalcin and Mollinga 2006, Wegerich 2009, P 1, P 58). In the following period, the province water management organizations were replaced by organizations established along hydrological boundaries. This reform remained rather superficial, however, since it changed neither informal institutions nor the influence of local administration on water distribution (P 76).

The dominance of the rigid agricultural sector over the water sector often hinders change in the water sector (Abdullaev et al. 2007). Even today, institutions such as the state order system restrict experimentation and innovation in water use. The state order system limits crop diversity and restricts farmers from adapting to changing water availability, for instance by changing cropping patterns or applying traditional water-saving methods (Thurman 2001, Hofman 2007). As a consequence of this mismanagement of the ecological and social resources, cotton yields as well as quality continue to decrease (Peyrouse 2009).

A recent example of the resistance of the system towards adaptive and transformative change was observed in the agricultural sector. After the global financial crisis hit Russia and Kazakhstan in 2008, the Uzbek social system became exposed to disturbance in the form of thousands of migrant workers returning to their Uzbek villages. Instead of creating an enabling environment for new jobs (such as through loosening the state order system), the Uzbek government reacted by issuing instructions for local administrations to make farmers hire workers in order to absorb the additional labor force. Since under the state order, farmers were not able to pay additional farm workers, they reportedly created false lists with names of people they allegedly hired in order to appease the local administration (IWPR 2009). These marginal changes represent single-loop learning and do not seem to be suited to adapting the SES and preparing it for similar disturbances in the future.

In Uzbekistan, informal institutions often run contrary to formal institutions, thus rendering rigid formal institutions rather meaningless for day-to-day water management (Helmke and Levitsky 2004). Formally, water is allocated according to the amount applied for. In practice-especially downstream - farmers often do not receive their share because access to water is highly dependent on economic and political ties (Veldwisch 2008). Formally, limits for water use are set, and overuse is sanctioned with penalties. In practice, however, exceeding the limit is often possible without sanctions (Veldwisch 2008). To prevent illegal pumping by upstream users, WUA managers use personal ties with electricity providers to switch off electricity in the upstream region in order to provide enough flow for the downstream users (Abdullaev et al. 2008). Formally, WUA managers are elected by the WUA members, and the WUAs are constructed as independent organizations. In practice, however, WUA managers are usually appointed by the local governor. Governors are personally responsible for delivering the amounts of cotton and wheat prescribed by the state order. This creates great incentives for them to interfere in water allocation, and the governors reportedly give instructions to WUA managers on a daily basis (Veldwisch 2008).

\section{Discussion: persistence of Uzbek water institutions}

The Uzbek case mirrors pathological resource management (Gunderson and Pritchard 2002). Soviet water managers were successful in achieving the narrowly defined goal of providing enough water for cotton monoculture in the Central Asian republics. This success encouraged the rapid enlargement of irrigated agriculture in the region (K-phase) and the overuse of water resources, leading to the desiccation of the Aral Sea. As a result, Uzbekistan is highly dependent on agricultural production today, especially cotton, and the unsustainable use of its water resources.

The newly established Republic of Uzbekistan did not use the crisis of the breakdown of the Soviet Union to adapt or transform its institutional system to better fit the demands of a changing SES. This has been called the "Soviet syndrome", i.e., the conservation of an authoritarian political system 
despite formal implementation of a democratic constitution and rule of law (Tolipow 2009). Institutional change is gradual at best and often not fully implemented (Schlüter and Herrfahrdt-Pähle 2011). The economy, and especially export commodities such as cotton, are still tightly controlled by the state (ICG 2007).

Water is rationed and reused during drought years, and rice planting is prohibited. Both measures are incremental and short-term reactions (single-loop learning) when actually long-term, transformative solutions are needed to significantly reduce water use and provide environmental flows. These solutions include a switch to less water-intensive crops (double-loop learning) and a reduction in agricultural activity (triple-loop learning). The switch could be supported by transforming the water law such that it addresses recent social and ecological changes and provides a stable legal basis for WUAs. Instead, a strong belief in technical solutions prevails and limits the space for alternative approaches. For example, government authorities still perceive the Soviet plan to divert water from the Siberian rivers to Central Asia as a viable solution to water scarcity instead of curbing water demand and settling international disputes over water (P 4).

Institutional change is realized mostly via decrees, bypassing the legislative, which adds uncertainty and a lack of transparency in the institutional system. Selectively, new rules have been introduced where there were incentives for them, which has created an institutional patchwork. New institutions are isolated, and no consistent approach to water sector reforms is observable. This small-scale approach does not seem appropriate for solving large-scale problems such as the transformation of a socialist system into a democratic, marketoriented one, or the desiccation of the Aral Sea and adaptation to climate change.

\section{CASE STUDY SOUTH AFRICA}

South African water resources are unevenly distributed across the country. As a consequence, South Africa developed an extended system of dams and (international) water transfer schemes (Muller 2002). However, in water-scarce years, the provision of irrigation water to farmers has to be curbed ( $\mathrm{P}$ 37). Access to safe drinking water and sanitation is far from comprehensive, but progress has been made in recent years (Bohensky and Lynam 2005).

South Africa has been undergoing transformation since the end of the apartheid regime in 1994. After years of economic sanctions, domestic markets and foreign trade were liberalized, and a parliament was democratically elected. Between 2000 and 2006, income poverty declined from 33.5\% to $25.3 \%$ (Republic of South Africa 2010). In addition to these paramount political, economic, and social changes, the country is projected to be highly affected by extreme ecological changes as a consequence of climate change. For example, by 2100 , temperatures are projected to rise by roughly 1.5 times the global mean increase (Christensen et al. 2007). Rising mean temperatures and changes in runoff and hydrology can already be detected (Kruger and Shongwe 2004, Boko et al. 2007).

\section{Institutional continuity and change since the end of the apartheid era}

During the apartheid era, the South African social system was rather resistant to change. In the water sector, the persistence of institutions such as the Water Act of 1956 accumulated pressure for change: most of the population was excluded from decision-making and was not adequately provided with drinking water and sanitation, and the ecological impacts of water use were ignored (Bohensky and Lynam 2005, Bohensky 2008). Large-scale irrigation agriculture was subsidized through capital-intensive engineering projects such as dams and water transfer schemes (Stein 2005, P 36). These were associated with the well-known negative effects in the social system (such as resettlement of mostly poor and black communities to marginal lands) and in the ecological system (such as impacts on water quality and quantity, downstream floodplains, and migratory fish species)(Bohensky and Lynam 2005).

Following the end of the apartheid regime in 1994, the South African social system transformed its constitutional rules, beginning with a new constitution (Republic of South Africa 1996) and followed by the Water Services Act (Republic of South Africa 1997) and the National Water Act (Republic of South Africa 1998). The latter has been internationally praised for representing state-of-the-art water law because it places basic equitable access to water and environmentally sustainable water use at the top of the agenda (de Coning and Sherwill 2004). Later, the National Water Resource Strategy (DWAF 2004) was developed to support the implementation of these ambitious laws. In line with the new constitution, all of the new institutions are based on equity, sustainability, and efficiency, and thus represent a clear break from the former institutions of the apartheid regime. Water rights are no longer tied to land rights, basin management and Catchment Management Agencies (CMAs, organizations based on stakeholder participation and decentralized water management) were introduced, programs for the nation-wide provision of drinking water and sanitation were initiated, and environmental flows are ensured through the establishment of an environmental reserve of water resources. Some of the former institutions have remained, however, to provide planning reliability for water users. For example, water rights that lawfully existed under apartheid law will be acknowledged until a license needs to be applied for under the new water law or the law foresees otherwise (Republic of South Africa 1998).

South African water governance institutions display a high level of flexibility. Under South African law, different parts 
of a new legislation can be promulgated at different times. Thus, the largest part of the National Water Act was promulgated in August 1998, but sensitive sections, such as the ones on licensing and levying water charges, were promulgated only a year later (Republic of South Africa 1998). The National Water Act provides a framework, and the elaboration of regulations takes place during implementation. By means of this enabling legislation, the authority for developing legal instruments and supporting policies for implementation is transferred to the state administration in charge (in this case, the Department of Water Affairs [DWA]) and thus can be tailored to the particular needs of the situation. In the case of the establishment of Catchment Management Agencies at the meso-level, however, this flexibility has had negative repercussions inasmuch as the Act did not specify criteria for CMA proposals. As a consequence, the DWA had to develop these criteria first, thus greatly delaying the assessment of CMA proposals (Brown and Woodhouse 2004, Herrfahrdt-Pähle 2010).

The National Water Act was designed to allow for a high degree of flexibility in its implementation. Expressions like "in a phased and progressive manner" allow for the gradual implementation of the Act over both time and space and its adaptation to local circumstances (Rowlston et al. 2000). This phased approach was deemed necessary due to the comprehensive changes the Act required and to the limited (human and financial) resources available for its implementation (de Coning 2006).

An example of the flexibility of South African water institutions are water licenses. These licenses are granted for a period not longer than 40 years and are subject to review every five years (Republic of South Africa 1998). Since the reallocation of water (from relatively low productivity uses, such as agriculture, to industry) is being discussed in South Africa (Otieno and Ochieng 2004), this flexibility may prove helpful. Should there be political consensus on the issue, the review of licenses every few years would allow for the implementation of such change. Also, the National Water Act foresees a revision of the National Water Resource Strategy every five years in order to identify any need for adaptation (Republic of South Africa 1998). However, the first revision, which would have been due in 2009, is still ongoingindicating that the ambitious goals may not always be met in the context of limited financial and human resources.

Catchment management forums provide an example of the ability to learn and the flexibility of the legislative framework. These forums, which are not mentioned in the National Water Act, are implemented at a sub-catchment level below CMAs to enable discussions and participation at the local level (P 26). After their usefulness for water management and for establishing CMAs became evident, however, the National Water Resource Strategy explicitly mentioned their positive role in transmitting local knowledge and facilitating stakeholder participation, and encourages the founding of such forums (Karar 2003, DWAF 2004).

Unlike the new set of formal institutions, some informal institutions remain rather rigid. Similar to the Uzbek case, the technical control paradigm and hydraulic mission, which characterized the water sector during the apartheid era and resulted in an extensive water infrastructure of dams and water transfer schemes, is still prevalent (Swatuk 2008, 2009). This strong belief in technical solutions to water scarcity currently undermines the needed innovation to confront the (future) impacts of climate change (such as the change from supply to demand management of water resources; P 37).

\section{Discussion: transformative change of South African water institutions}

The crisis ( $\Omega$-phase) and the end of the apartheid system have been used to introduce paramount change in the social, economic, and political subsystems of the South African SES. In particular, South African water governance is in the phase of implementing and consolidating new institutions (r-phase). The paramount changes introduced with the National Water Act and other legislation indicate triple-loop learning and a transformation (Bohensky 2008). The water sector was able to develop and enact a completely new body of water legislation, which better fits the new socioeconomic and environmental needs. The new institutional structure thus provides stability in the short term (through a national water law that may not be altered at short notice) while leaving room to maneuver for adaptation if needed in the future (long-term flexibility). For example, the implementation of CMAs simultaneously in all catchments was abandoned once it became obvious that it was too ambitious. However, the possibility of postponing implementation also entails the danger of lack of commitment from the government in generating the enabling conditions for implementation. It must be noted that South Africa is struggling with the implementation of the ambitious new water legislation. Slow progress is being made in implementing CMAs, determining the environmental reserve, and establishing inclusive stakeholder participation (P 16, P 34). Thus, the South African system seems to be experiencing extensive change of constitutional rules while collective choice and operational rules lag behind.

The literature stresses the role of leadership in building resilience (Folke et al. 2005, Gupta et al. 2010). At the national level, a knowledgeable and visionary minister initiated comprehensive reforms in the first few years after democratization. Consistency was provided through a skilled director general at the DWA. He was a knowledgeable reformer and remained in office despite changing ministers and thus served as a stabilizing factor (P 16, P 27). At the same time, large parts of human expertise were lost in the DWA 
(Bohensky and Lynam 2005). The senior water managers were replaced by less experienced young staff for a number of reasons, including the Black Economic Empowerment policy. Furthermore, many senior managers reached retirement age, the private sector pays better than the public sector, and HIV AIDS took its toll (P 15, P 36, P 36). All these factors contributed to a loss of memory in the water sector and impaired the ability of the administration to efficiently implement reforms, especially at the meso level. On the one hand, this loss of memory was intended, since large parts of the apartheid system were obsolete. On the other hand, the panarchy concept requires a certain amount of memory and stability for a system, even during transformation phases, to prevent the system from collapsing. The all-encompassing new legislation seems to be too ambitious to be implemented by an administrative body that has been weakened by brain drain and has had relatively inexperienced staff enter the system. The memory function at this level of administration might be lost, adding to instability and change. It may thus be proposed that the transformation of constitutional rules requires a certain amount of stability in staff to provide for memory and expertise.

At the moment, the institutional resilience of the water sector is slowly increasing. The new set of constitutional rules provides a solid basis for sustainable water resource management even as they leave room for adaptation and for addressing potential environmental and social changes. The slow progress of reforms, however, puts policy-makers under pressure. Recently, voices have been raised that have questioned the usefulness of IWRM and CMAs, and have suggested reforming the reform process, e.g., by reducing the number of CMAs (P 16). Huntjens et al. (2008) already detect a change in government policy from a more participatory towards a command-and-control paradigm. Likewise, the environmental reserve is being questioned by politicians since water resources are becoming scarce. One respondent from the DWA reported having been criticized in Parliament for slow progress in water governance reforms (P 43). If these trends persist, the new institutions might not be allowed to become established. This means a hasty entrance of another adaptive cycle, i.e., the direct transition from the r-phase to the $\Omega$-phase (Walker and Salt 2006). One possible outcome could be too much change and a lack of consolidation and consistency. The new regime may not be able to stabilize fast enough for reforms to take effect after the breakdown of the old regime (Young 2010).

\section{CONCLUSION}

In both case studies, great pressure for change accumulated over the decades as the respective countries were locked in resistant, maladaptive regimes. While the Uzbek social system disregarded environmental change, the South African social system mainly accumulated a need for change with regard to social injustice. In both cases, a transformative change of the
SES seems to be required, since incremental change or adaptation would not be sufficient to tackle the problems.

The case studies illustrate a number of advantages and disadvantages of either too much continuity or too much change of formal institutions, while informal institutions in both cases remain rather rigid, thus hindering change. In the Uzbek case, the de facto persistence of the formal institutional framework and the dominance of rigid informal institutions over both old and (selectively introduced) new formal institutions provided a high level of continuity. However, this continuity and stability was traded off against a lack of consistency and transparency in the reform process as well as against effectively addressing massive overuse of water resources and environmental degradation. Furthermore, the performance of isolated new institutions was undermined by rigid institutions in other sectors.

In South Africa, on the contrary, the comprehensive change in the formal institutions in the water sector (constitutional rules) led to a consistent new approach to water management, which addressed pressing issues, such as equitable access to drinking water and environmental flows. The downside was the time and resources required to implement this approach. Implementing the ambitious new framework (i.e., transferring it to collective choice and operational rules) overburdened administrative structures and resulted in a lengthy reform process, lacking commitment, and resulted in policy fatigue among successional decision-makers and water managers.

From the case studies, some propositions can be derived about the need for change and flexibility during consolidation of water governance reform:

3. The flexibility of the legislation and legislative process seems to be an important factor (such as the provision of phased approaches). An enabling legislation, as implemented in South Africa, allows single parts to be adapted without questioning the whole legislation, while amending Uzbek water law (to include, for example, provisions for WUAs) is a lengthy process. However, caution needs to be taken since a phased approach, as in South Africa, also takes time, and institutional stability should not be jeopardized.

4. During the implementation process, institutional flexibility seems to be essential. This includes the possibility of adapting the legal framework during implementation (for instance, sequencing of implementation if legal provisions cannot be established at once, as in South Africa, or adapting institutions in other sectors, as required in Uzbekistan).

5. Flexibility regarding outcomes seems to be necessary. In the context of changing water availability, it is important to secure water rights but at the same time retain flexibility in water allocation over time. Should water 
become even scarcer in the future, regular revisions of water rights will allow for their reallocation.

6. The intervals at which institutions are reviewed and (if they are no longer appropriate) reauthorized may need to be shorter (Young 2010). National water legislation could better fit changing social and ecological conditions if it were not transformed in intervals of several decades but rather if it were reviewed and the necessary adaptations were made at shorter intervals, for instance every 10 years. However, this requirement needs to be contrasted with limited human and financial resources.

The following propositions can be put forward for the need for continuity during transformation:

7. Enhanced or stabilized social memory seems to be an important factor during the transformation of institutional systems (Bohensky and Lynam 2005). In particular, the South African case study shows how important knowledgeable people are in key positions (lack of senior managers, continuity through the director general). It seems that in order to secure pertinent information and expertise, at least part of the staff of water management organizations should remain as resource persons.

8. Another lesson from the South African case is the sequencing of phases of major disruption and change and the importance of a phase of consolidation thereafter (Folke et al. 2010). If the success of a transformation process is questioned before it is able to materialize and a new set of institutions is installed, the amount of change may overburden the system's capacity (e.g., human capacity).

9. The differentiation between different kinds of institutions seems appropriate. Not all institutions must persist as long as those institutions that define how the rules are made (i.e., constitutional rules) remain in place and are adhered to. If this is acknowledged, and formal and informal institutions are aligned, institutions can be revised as long as they follow the usual procedures; this will automatically restrict the frequency of changing them. In Uzbekistan, however, formal and informal institutions are often not in line, and the president rules by decree, thus circumventing the approval of the legislative assembly. Ruling by decree opens up room for flexibility, which may not be favorable at this institutional level since it increases institutional uncertainty.

10. The transparency of processes seems to be important during transformation. Stability is provided if the rulemaking process is transparent and acknowledged by all water users (as opposed to ruling by decree or water being distributed by way of social ties, as in Uzbekistan).
Responses to this article can be read online at: http://www.ecologyandsociety.org/vol17/iss2/art8/responses/

\section{Acknowledgments:}

The authors wish to thank Carl Folke, Maja Schlüter, and three anonymous reviewers for their helpful comments on the manuscript. We acknowledge the support of the NeWater Project, which was financially supported by the European Commission (Contract No. 511179 - NEWATER).

\section{LITERATURE CITED}

Abdullaev, I., J. Kazbekov, H. Manthrithilake, K. Jumaboev, and M. Yakubov. 2007. Institutional reforms at main canal level and its water management implications: case from South Ferghana Canal, Uzbekistan. International Water Management Institute.

Abdullaev, I., F. Nurmetova, F. Abdullaeva, and J. Lamers. 2008. Socio-technical aspects of water management in Uzbekistan: emerging water governance issues at the grass root level. Pages 89-103 in M. M. Rahaman and O. Varis, editors. Central Asian waters: social, economic, environmental and governance puzzle. Water \& Development Publications, Helsinki University of Technology, Helsinki, Finland.

Adger, N. W. 2003. Governing natural resources: institutional adaptation and resilience. Pages 193-208 in F. Berkhout, M. Leach, and I. Scoones, editors. Negotiating environmental change: new perspectives from social science. Edward Elgar, Cheltenham, UK.

Allison, H. E., and R. J. Hobbs. 2004. Resilience, adaptive capacity, and the "lock-in trap" of the Western Australian agricultural region. Ecology and Society 9(1):3. [online] URL: http://www.ecologyandsociety.org/vol9/iss1/art3/

Berkes, F., J. Colding, and C. Folke, editors. 2003. Navigating social-ecological systems: building resilience for complexity and change. Cambridge University Press, Cambridge, UK.

Bertelsmann Foundation. 2008. Bertelsmann Transformation Index 2008. Bertelsmann Foundation, Gütersloh. [online] URL: http://www.bertelsmann-stiftung.de/cps/rde/xchg/bst/hs. xsl/publikationen_85140.htm

Bohensky, E. L. 2008. Discovering resilient pathways for South African water management: two frameworks for a vision. Ecology and Society 13(1):19. [online] URL: http://w ww.ecologyandsociety.org/vol13/iss1/art19/

Bohensky, E. L., and T. Lynam. 2005. Evaluating responses in complex adaptive systems: insights on water management from the Southern African Millennium Ecosystem Assessment (SAfMA). Ecology and Society 10(1):11. [online] URL: http://www.ecologyandsociety.org/vol10/iss1/art11/ 
Boko, M., I. Niang, A. Nyong, C. Vogel, A. Githeko, B. Osman-Elasha, R. Tabo, and P. Yanda. 2007. Africa in M. L. Parry, O. F. Canziani, J. P. Palutikof, P. J. Van der Linden, and C. E. Hanson, editors. Climate change 2007: impacts, adaptation and vulnerability. Contribution of Working Group II to the fourth assessment report of the Intergovernmental Panel on Climate Change. Cambridge University Press, Cambridge, UK.

Brown, J., and P. Woodhouse. 2004. Pioneering redistributive regulatory reform: a study of implementation of a Catchment Management Agency for the Inkomati Water Management Area, South Africa. Working Paper 89, Centre on Regulation and Competition, Manchester, UK.

Carmel, J. 2005. Machteliten Usbekistans: clans oder politische Allianzen? Orient 46:581-608.

Christensen, J. H., B. Hewitson, A. Busuioc, A. Chen, X. Gao, I. Held, R. Jones, R. K. Kolli, W. T. Kwon, R. Laprise, V. Magana Rueda, L. Mearns, C. G. Menéndez, J. Räisänen, A. Rinke, A. Sarr, and P. Whetton. 2007. Regional climate projections. Pages 847-940 in S. Solomon, D. Qin, M. Manning, Z. Chen, M. Marquis, K. B. Averyt, M. Tignor, and H. L. Miller, editors. Climate change 2007: the physical science basis. Contribution of Working Group I to the fourth assessment report of the Intergovernmental Panel on Climate Change. Cambridge University Press, Cambridge, UK.

Cruz, R. V., H. Harasawa, M. Lal, S. Wu, Y. Anokhin, B. Punsalmaa, Y. Honda, M. Jafari, C. Li, and N. Huu Ninh. 2007. Asia. Pages 469-506 in M. L. Parry, O. F. Canziani, J. P. Palutikof, P. J. van der Linden, and C. E. Hanson, editors. Climate change 2007: impacts, adaptation and vulnerability. Contribution of Working Group II to the fourth assessment report of the Intergovernmental Panel in Climate Change. Cambridge University Press, Cambridge, UK.

David, P. A. 2002. Path dependence, its critics and the quest for 'historical economics'. Pages 79-104 in T. Cowen and E. Crampton, editors. Market failure or success: the new debate. Edward Elgar, Cheltenham, UK.

de Coning, C. 2006. Overview of the water policy process in South Africa. Water Policy 8:505-528. http://dx.doi.org/10.2 166/wp.2006.039

de Coning, C., and T. Sherwill. 2004. An assessment of the water policy process in South Africa (1994-2003). Water Research Commission, Pretoria, South Africa.

Department of Water Affairs and Forestry (DWAF). 2004. National water resource strategy: 'Our blue print for survival'. Pretoria, South Africa. [online] URL: http://www.dwaf.gov.za/ Documents/Policies/NWRS/Default.htm

Folke, C. 2006. Resilience: the emergence of a perspective for social-ecological systems analyses. Global Environmental
Change 16:253-267. http://dx.doi.org/10.1016/j.gloenvcha.20 $\underline{06.04 .002}$

Folke, C., S. Carpenter, B. Walker, M. Scheffer, T. Chapin, and J. Rockström. 2010. Resilience thinking: integrating resilience, adaptability and transformability. Ecology and Society 15(4):20. [online] URL: http://www.ecologyandsociety. org/vol15/iss4/art20/

Folke, C., T. Hahn, P. Olsson, and J. Norberg. 2005. Adaptive governance of social-ecological systems. Annual Review of Environment and Resources 30:441-473. http://dx.doi.org/10 .1146/annurev.energy.30.050504.144511

Folke, C., L. Pritchard, F. Berkes, J. Colding, and U. Svedin. 1998. The problem of fit between ecosystems and institutions. IHDP Working Paper No. 2, International Human Dimensions Programme.

Food and Agriculture Organization of the United Nations (FAO). 2010. AQUASTAT: FAO's information system on water and agriculture. [online] URL: http://www.fao.org/nr/water/a quastat/main/index.stm

Food and Agriculture Organization of the United Nations (FAO). 2011. FAOSTAT. [online] URL: http://faostat.fao.org/ default.aspx

Gunderson, L. H., S. R. Carpenter, C. Folke, P. Olsson, and G. Peterson. 2006. Water RATs (resilience, adaptability, and transformability) in lake and wetland social-ecological systems. Ecology and Society 11(1):16. [online] URL: http:// www.ecologyandsociety.org/vol11/iss1/art16/

Gunderson, L. H., and C. S. Holling, editors. 2002. Panarchy: understanding transformations in human and natural systems. Island Press, Washington, D.C., USA.

Gunderson, L. H., C. S. Holling, and S. S. Light. 1995. Barriers broken and bridges built: a synthesis. Pages 489-532 in L. H. Gunderson, C. S. Holling, and S. S. Light, editors. Barriers and bridges to the renewal of ecosystems and institutions. Columbia University Press, New York, New York, USA.

Gunderson, L. H., C. S. Holling, L. Pritchard, and G. D. Peterson. 1997. Resilience in ecosystems, institutions, and societies: propositions for a research agenda. Beijer International Institute of Ecological Economics, The Royal Swedish Academy of Sciences, Stockholm, Sweden.

Gunderson, L. H., and L. Pritchard, editors. 2002. Resilience and the behavior of large-scale systems. Island Press, Washington, D.C., USA.

Gupta, J., C. Termeer, J. Klostermann, S. Meijerink, M. v. d. Brink, P. Jong, S. Nooteboom, and E. Bergsma. 2010. The adaptive capacity wheel: a method to assess the inherent characteristics of institutions to enable the adaptive capacity of society. Environmental Science and Policy 13:459-471. http://dx.doi.org/10.1016/j.envsci.2010.05.006 
Handmer, J., and S. Dovers. 2009. A typology of resilience: rethinking institutions for sustainable development. Pages 187-210 in E. L. F. Schipper and I. Burton, editors. Adaptation to climate change. Earthscan, London, UK. http://dx.doi.org/ $\underline{10.1177 / 108602669600900403}$

Helmke, G., and S. Levitsky. 2004. Informal institutions and comparative politics: a research agenda. Perspectives on Politics 2:725-740. http://dx.doi.org/10.1017/S1537592704040472

Herrfahrdt, E. 2004. Landwirtschaftliche Transformation, Desertifikation und nachhaltige Ressourcennutzung: Fallbeispiel Usbekistan. Studies 2, German Development Institute, Bonn, Germany.

Herrfahrdt-Pähle, E. 2010. The transformation towards adaptive water governance regimes in the context of climate change. Thesis, University of Osnabrück, Osnabrück, Germany.

Hofman, I. 2007. Agrarian reform...the pathway to sustainability? The case or Urta, Yukori and Quyi Chirchik. Wageningen University, Wageningen, The Netherlands.

Holl, C. 2002. Entstehung und Wandel von Institutionen. North und Hayek im Vergleich. Paper presented at the third workshop "Ordnungsökonomik und Recht" in Bleibach/ Gutach, 11-12 Oktober 2002.

Holling, C. S., and L. H. Gunderson. 2002. Resilience and adaptive cycles. Pages 25-62 in L. H. Gunderson and C. S. Holling, editors. Panarchy: understanding transformations in human and natural systems. Island Press, Washington, D.C., USA.

Holling, C. S., L. H. Gunderson, and G. D. Peterson. 2002. Sustainability and panarchies. Pages 63-102 in L. H. Gunderson and C. S. Holling, editors. Panarchy: understanding transformations in human and natural systems. Island Press, Washington, D.C., USA.

Holling, C. S., and G. K. Meffe. 1996. Command and control and the pathology of natural resource management. Conservation Biology 10:328-337. http://dx.doi.org/10.1046/ j.1523-1739.1996.10020328.x

Huitema, D., E. Mostert, W. Egas, S. Moellenkamp, C. PahlWostl, and R. Yalcin. 2009. Adaptive water governance: assessing the institutional prescriptions of adaptive (co-) management from a governance perspective and defining a research agenda. Ecology and Society 14(1):26. [online] URL: http://www.ecologyandsociety.org/vol14/iss1/art26/

Huntjens, P., C. Pahl-Wostl, B. Rihoux, Z. Flachner, S. Neto, R. Koskova, M. Schlueter, I. Nabide Kiti, and C. Dickens. 2008. The role of adaptive and integrated water management $(A I W M)$ in developing climate change adaptation strategies for dealing with floods and droughts: a formal comparative analysis of eight water management regimes in Europe, Asia and Africa. Deliverable $1.79 \mathrm{~b}$ of the Newater Project, University of Osnabrück, Osnabrück, Germany. [online] URL: http://www.newater.uni-osnabrueck.de/intern/sendfile. php?id=814

Institute for War \& Peace Reporting (IWPR). 2009. Rural job scheme hits Uzbek farmers' pockets. Reporting Central Asia No. 578. [online] URL: http://www.iwpr.net/report-news/ruraljob-scheme-hits-uzbek-farmers'-pockets

International Crisis Group (ICG). 2007. Uzbekistan: stagnation and uncertainty. International Crisis Group, Bishkek/Brussels, Belgium.

International Water Management Institute and ScientificInformation Center of the Interstate Coordination Water Commission of Central Asia (IWMI and SIC ICWC). 2003. How to establish a Water Users Association? Practical steps for social mobilizers. IWMI, SIC-ICWC, Tashkent, Uzbekistan.

Janssen, M. A. 2002. A future of surprises. Pages 241-260 in L. H. Gunderson and C. S. Holling, editors. Panarchy: understanding transformations in human and natural systems. Island Press, Washington, D.C., USA.

Karar, E. 2003. Governance in water resources management: progress in South Africa. Department of Water Affairs and Forestry, Pretoria, South Africa.

Kruger, A. C., and S. Shongwe. 2004. Temperature trends in South Africa: 1960-2003. International Journal of Climatology 24:1929-1945. http://dx.doi.org/10.1002/joc.1096

Micklin, P. P. 1988. Desiccation of the Aral Sea: a water management disaster in the Soviet Union. Science 241:11701176. http://dx.doi.org/10.1126/science.241.4870.1170

Muller, M. 2002. Inter-basin water sharing to achieve water security - a South African perspective. Department of Water Affairs and Forestry, Pretoria, South Africa.

North, D. C. 1990. Institutions, institutional change and economic performance. Cambridge University Press, Cambridge, UK.

North, D. C. 1993. Institutional change: a framework of analysis. Pages 35-46 in S.-E. Sjöstrand, editor. Institutional change: theory and empirical findings. ME Sharpe, Armonk, New York, USA.

Ostrom, E. 1990. Governing the commons: the evolution of institutions for collective action. Cambridge University Press, Cambridge, UK.

Ostrom, E. 2005. Understanding institutional diversity. Princeton University Press, Princeton, New Jersey, USA. 
Otieno, F. A. O., and G. M. M. Ochieng. 2004. Water management tools as a means of averting a possible water scarcity in South Africa by the year 2025. Water SA 30:120124.

Paavola, J. 2007. Institutions and environmental governance: a reconceptualization. Ecological Economics 63:93-103. htt p://dx.doi.org/10.1016/j.ecolecon.2006.09.026

Pahl-Wostl, C. 2009. A conceptual framework for analysing adaptive capacity and multi-level learning processes in resource governance regimes. Global Environmental Change 19:354-365. http://dx.doi.org/10.1016/j.gloenvcha.2009.06.001

Palley, T. 2009. America's exhausted paradigm: macroeconomic causes of the financial crisis and great recession. New America Foundation, Washington, D.C., USA.

Pejovich, S. 1999. The effects of the interaction of formal and informal institutions on social stability and economic development. Journal of Markets \& Morality 2:164-181.

Peyrouse, S. 2009. The multiple paradoxes of the agriculture issue in Central Asia. Working Paper 6, EU Central Asia Monitoring, Brussels, Belgium.

Pierson, P. 2000. Increasing returns, path dependence, and the study of politics. American Political Science Review 94:251267. http://dx.doi.org/10.2307/2586011

Republic of South Africa. 1996. Constitution of the Republic of South Africa. Republic of South Africa, Pretoria, South Africa.

Republic of South Africa. 1997. Water Services Act, 1997. Government Gazette, Republic of South Africa, Cape Town, South Africa.

Republic of South Africa. 1998. National Water Act-Act No 36 of 1998. Republic of South Africa, Pretoria, South Africa.

Republic of South Africa. 2010. Millenium Development Goals country report for 2010. [online] URL: http://www.sta tssa.gov.za/nss/documents/Concept\%20Paper\%20for\%20MDG\% 202010\%20Final\%20Draft_2_3_4_aposteriori.pdf

Republic of Uzbekistan. 1993. Law on water and water use. Tashkent, Uzbekistan.

Republic of Uzbekistan. 1998. Land Code of the Republic of Uzbekistan. Tashkent, Uzbekistan.

Republic of Uzbekistan. 2003. Decree on the major directions of reforms in the agricultural sector. Tashkent, Uzbekistan.

Rockström, J., W. Steffen, K. Noone, Å. Persson, F. S. I. Chapin, E. Lambin, T. M. Lenton, M. Scheffer, C. Folke, H. J. Schellnhuber, B. Nykvis, C. A. d. Wit, T. Hughes, S. v. d.
Leeuw, H. Rodhe, S. Sörlin, P. K. Snyder, R. Costanza, U. Svedin, M. Falkenmark, L. Karlberg, R. W. Corell, V. J. Fabry, J. Hansen, B. Walker, D. Liverman, K. Richardson, P. Crutzen, and J. Foley. 2009. Planetary boundaries: exploring the safe operating space for humanity. Ecology and Society 14(2):32. [online] URL: http://www.ecologyandsociety.org/vol14/iss2/ $\underline{\operatorname{art} 32 /}$

Rowlston, B., B. Barta, and J. Mokonyane. 2000. Implementing new water law: a South African experience. XTH World Water Congress, Melbourne, Australia.

Schlüter, M., and E. Herrfahrdt-Pähle. 2011. Exploring resilience and transformability of a river basin in the face of socio-economic and ecological crisis - an example from the Amudarya River Basin, Central Asia. Ecology and Society 16 (1):32. [online] URL: http://www.ecologyandsociety.org/vol16/ iss1/art32/main.html

Stein, R. 2005. Water law in a democratic South Africa: a country case study examining the introduction of a public rights system. Texas Law Review 83:2167-2183.

Swatuk, L. A. 2008. A political economy of water in Southern Africa. Water Alternatives 1:24-47.

Swatuk, L. A. 2009. The state and water resources development: a tale of two South Africa's. International Workshop on Water Management in State-centric Regimes, Centre for Development Research, Bonn, Germany.

Thurman, M. 2001. Irrigation and poverty in Central Asia: a field assessment. World Bank, Washington, D.C., USA.

Tolipow, F. 2009. Die Beharrlichkeit des Vergangenen und Aufruf zu neuem Denken. Zentralasien-Analysen 19-20:212.

Transparency International. 2009. Corruption Perception Index. [online] URL: http://www.transparency.org/policy research/ surveys_indices/cpi/2009

Veldwisch, G. J. 2008. Cotton, rice \& water-the transformation of agrarian relations, irrigation technology and water distribution in Khorezm, Uzbekistan. University of Bonn, Bonn, Germany.

Walker, B., L. Gunderson, A. Kinzig, C. Folke, S. Carpenter, and L. Schultz. 2006. A handful of heuristics and some propositions for understanding resilience in social-ecological systems. Ecology and Society 11(1):13. [online] URL: http:// wWw.ecologyandsociety.org/vol11/iss1/art13/ES-2005-1530. pdf

Walker, B., C. S. Holling, S. R. Carpenter, and A. Kinzig. 2004. Resilience, adaptability and transformability in socialecological systems. Ecology and Society 9(2):5. [online] URL: http://www.ecologyandsociety.org/vol9/iss2/art5/ 
Walker, B., and D. Salt. 2006. Resilience thinking: sustaining ecosystems and people in a changing world. Island Press, Washington, D.C., USA.

Wegerich, K. 2001. Natural drought or human made water scarcity in Uzbekistan? Central Asia and the Caucasus 2(14), 2002.

Wegerich, K. 2009. Shifting to hydrological boundaries-the politics of implementation in the lower Amu Darya basin. Physics and Chemistry of the Earth, Parts A/B/C 34:279-288. http://dx.doi.org/10.1016/j.pce.2008.06.003

Williamson, O. E. 2000. The new institutional economics: taking stock, looking ahead. Journal of Economic Literature 38:595-613. http://dx.doi.org/10.1257/jel.38.3.595

World Bank. 2003. Uzbekistan: living standards assessment: policies to improve living standards (in two volumes): Volume I: summary report. World Bank, Washington, D.C., USA.

World Bank. 2009. Governance matters: worldwide governance indicators 1996-2008. World Bank, Washington, D.C., USA.

World Health Organization (WHO). 2008. WHO Statistical Information System (WHOSIS). [online] URL: http://www.w ho.int/whosis/en/

Yalcin, R., and P. P. Mollinga. 2006. Institutional transformation in Uzbekistan's agricultural and water resources administration: the creation of a new bureaucracy. Centre for Development Research, University of Bonn, Bonn, Germany.

Yalcin, R., and P. P. Mollinga. 2007. Water users associations in Uzbekistan: the introduction of a new institutional arrangement for local water management. Amи Darya case study-Uzbekistan. NeWater, Centre for Development Research, Bonn, Germany.

Young, O. 2002. The institutional dimensions of environmental change. MIT Press, Cambridge, Massachusetts, USA.

Young, O. 2010. Institutional dynamics: resilience, vulnerability and adaptation in environmental and resource regimes. Global Environmental Change 20:378-385. http://d x.doi.org/10.1016/j.gloenvcha.2009.10.001 